\title{
A Study on Physicochemical Quality of Bottled Natural Spring Waters Consumed in Sivas, Turkey
}

\author{
Seher Dirican" \\ Department of Crop and Animal Production, Vocational Training School of Suşehri Timur Karabal, Sivas \\ Cumhuriyet University TR-58600 Sivas, Turkey
}

*Corresponding Author: Seher Dirican, Department of Crop and Animal Production, Vocational Training School of Suşehri Timur Karabal, Sivas Cumhuriyet University TR-58600 Sivas, Turkey

\begin{abstract}
The present study is based on physicochemical quality examining of bottled natural spring waters being sold between February 2018 and January 2019 in central of Sivas. Physicochemical parameters contents in bottled natural spring water samples were pH 6.38 to 8.20, electrical conductivity 15.64 to 371.00 $\mu \mathrm{S} / \mathrm{cm}$, aluminum 0.21 to $66.60 \mu \mathrm{g} / \mathrm{L}$, ammonium 0.01 to $0.15 \mathrm{mg} / \mathrm{L}$, chloride 0.27 to $16.50 \mathrm{mg} / \mathrm{L}$, iron 0.35 to $55.10 \mu \mathrm{g} / \mathrm{L}$, manganese 0.03 to $3.00 \mu \mathrm{g} / \mathrm{L}$, oxidisability 0.20 to $2.32 \mathrm{mg} / \mathrm{L}$, sodium 0.66 to $67.30 \mathrm{mg} / \mathrm{L}$ and sulfate 0.80 to $22.60 \mathrm{mg} / \mathrm{L}$. The findings were checked and debated on the international limit values for drinking water quality. Bottled natural spring water samples in Sivas were within the acceptable standards for human consumption.
\end{abstract}

Keywords: Bottled, Natural, Spring, Water, Quality

\section{INTRODUCTION}

Water has become an increasingly important strategic resource in the world. Therefore, global and national sensitivity on water resources is increasing. Drinking water should always be healthy and reliable. At this point, the importance of bottled water is revealed. In recent years, the bottled water industry has become a rapidly growing market in all parts of the world. Due to the healthy lifestyle trend, better flavor, ease access and comparatively low cost in many countries, bottled water has taken its place as an indispensable part of daily life. Even in the remotest corners of the world, the bottled water is a key commodity. Globally, the total bottled water consumption topped 329.33 billion liters in 2015, an increase of more than $1 / 3$ in per capita terms over a span of five years. Bottled water initially emerged as a large, mainstream commercial beverage category in Western Europe and later expanded remarkably in the United States of America market. In the last few years, several Asian markets have become major bottled water markets (Qian, 2018). In Turkey, the consumption of bottled water was started in the mid 1980s and it has increased dramatically afterwards. In 2003, 81 liter of average per capita of bottled water was consumed in Turkey (KUDAKA, 2012). The average per capita consumption of bottled water reached 149 liter in 2017. The bottled water sector reached 11.6 billion liters with a $3 \%$ growth according to the data in 2017. At the same time, Turkey is exporting bottled water to approximately 70 countries. (SUDER, 2018). Nowadays, there are 349 domestic brands of bottled water were certified by the Republic of Turkey Ministry of Health. The aim of this study is to assess with labeled values the physicochemical parameters of different brands of bottled natural spring waters available in Sivas Province located at Central Anatolian region of Turkey.

\section{MATERIALS AND MeTHODS}

\subsection{Study Area}

Sivas is a province in central part of Turkey. Sivas is the second largest province of Turkey with an area $27202 \mathrm{~km}^{2}$. The total of Sivas area is $47.6 \%$ plateaus, $46.2 \%$ mountains and $6.2 \%$ plains. The average altitude of the province is about $1285 \mathrm{~m}$. Terrestrial climate prevails in Sivas. According to the climate, summers are hot and dry whereas winters are cold and snowy. The population of the central of Sivas is about 470589. According to indicators between 2017 and 2018 annual growth rate of population in central of Sivas was reported at 39.9\% (TURKSTAT, 2019). The 0.5 L bottled natural spring waters is commonly sold and consumed in central of Sivas. 


\subsection{Sample Collection and Data Comparison}

Branded natural spring waters sold in different markets and shops were identified in central of Sivas. Brands of plastic bottled natural drinking water were bought through random sampling from local markets and shops in central of Sivas during the period of February 2018 and January 2019. The holding capacities of the bottled water samples were $0.5 \mathrm{~L}$. A total of 18 brands of bottled natural drinking water were sampled in central of Sivas. To keep the brand names anonymous, number 1 to 18 were given to the water samples. Ten selected physicochemical parameters that are in the labels of these water samples were recorded for their $\mathrm{pH}$, electrical conductivity (EC), aluminum ( $\mathrm{Al}$ ), ammonium $\left(\mathrm{NH}_{4}\right)$, chloride $(\mathrm{Cl})$, iron $(\mathrm{Fe})$, manganese $(\mathrm{Mn})$, oxidisability $\left(\mathrm{O}_{2}\right)$, sodium $(\mathrm{Na})$ and sulfate $\left(\mathrm{SO}_{4}\right)$. These physicochemical parameter values are the license values taken from the Provincial Public Health Directorates of the Republic of Turkey Ministry of Health. It is also the Ministry of Health's Provincial Public Health Directorates that take the water sample and conduct the analyzes. Samples were analyzed by standard methods. All of these branded water samples were subjected to oxygenation process with ozone enriched air. It is bottled without hand touch on fully automatic machines. The results obtained were compared and discussed with acceptable limit for drinking water quality parameters provided from the ECDWD (1998), TWRHC (2005), EPA (2014) and WHO (2017).

\section{RESUlts}

Eighteen samples comprising brands of bottled natural spring waters available at the period of the study in central of Sivas were researched with labeled values for their ten physicochemical parameters. A total of $0.5 \mathrm{~L}$ bottled water samples belonging to 18 different brands were researched for their $\mathrm{pH}$, electrical conductivity, aluminum, ammonium, chloride, iron, manganese, oxidisability, sodium and sulfate. The physicochemical parameters of bottled natural spring waters in Sivas have been presented in Table 1. There are variations in the content of physicochemical parameters of bottled natural spring water samples consumed in Sivas. All of the bottled water samples examined are manufactured in different provinces of Turkey. According to their manufacture 18 locally manufactured from 1 Sivas's water brands and 17 water brands from different provinces in Turkey such as 3 Erzurum, 3 Bursa, 2 Giresun, 1 Bolu, 1 Elazı̆̆, 1 Kahramanmaraş, 1 Kocaeli, 1 Kayseri, 1 Kırşehir, 1 Sakarya, 1 Samsun and 1 Tokat. Color, flavor, odour and turbidity of all examined natural spring water samples were acceptable or suitable found within permissible limits.

Table1. The physicochemical parameters of bottled natural spring waters in Sivas.

\begin{tabular}{|c|c|c|c|c|c|c|c|c|c|c|c|c|}
\hline $\mathbf{N}$ & $\begin{array}{l}\text { Permite } \\
\text { Date }\end{array}$ & $\begin{array}{l}\text { Permite } \\
\text { Number }\end{array}$ & pH & $\begin{array}{c}\mathrm{EC} \\
\mu \mathrm{S} / \mathrm{cm}\end{array}$ & $\begin{array}{c}\mathrm{Al} \\
\mu \mathrm{g} / \mathrm{L}\end{array}$ & $\begin{array}{c}\mathrm{Fe} \\
\mu \mathrm{g} / \mathrm{L}\end{array}$ & $\begin{array}{c}\mathrm{Mn} \\
\mu \mathrm{g} / \mathrm{L}\end{array}$ & $\begin{array}{l}\mathrm{NH}_{4} \\
\mathrm{mg} / \mathrm{L}\end{array}$ & $\begin{array}{c}\mathrm{Cl} \\
\mathrm{mg} / \mathrm{L}\end{array}$ & $\begin{array}{c}\mathrm{O}_{2} \\
\mathrm{mg} / \mathrm{L}\end{array}$ & $\begin{array}{c}\mathrm{Na} \\
\mathrm{mg} / \mathrm{L}\end{array}$ & $\begin{array}{c}\mathrm{SO}_{4} \\
\mathrm{mg} / \mathrm{L}\end{array}$ \\
\hline 1 & 26.07 .2010 & KS.14.02 & 7.20 & 75.40 & - & - & - & - & - & 1.00 & 0.66 & 0.80 \\
\hline 2 & 16.01 .2012 & KS.16.16 & 7.80 & 146.70 & - & - & - & - & 0.76 & 0.46 & 1.57 & 7.00 \\
\hline 3 & 03.02 .2012 & KS.16.17 & 7.68 & 156.30 & - & - & - & - & 1.00 & 0.41 & 1.98 & 7.65 \\
\hline 4 & 11.12 .2015 & KS.16.25 & 7.76 & 54.60 & 2.00 & 1.00 & 1.00 & 0.03 & 0.80 & 0.20 & 2.66 & 3.69 \\
\hline 5 & 22.05 .2012 & KS.23.01 & 8.20 & 167.14 & 0.21 & - & - & 0.02 & 0.87 & - & 3.32 & 5.00 \\
\hline 6 & 18.11 .2009 & KS.25.01 & 7.42 & 83.10 & 4.00 & 1.39 & 1.16 & 0.05 & 0.43 & 1.60 & 7.34 & 2.72 \\
\hline 7 & 16.01 .2012 & İS.25.01 & 7.35 & 112.60 & 1.74 & 2.41 & 0.07 & 0.15 & 1.39 & 1.04 & 1.65 & 1.95 \\
\hline 8 & 07.02 .2013 & KS.25.05 & 7.59 & 87.70 & 2.30 & 0.92 & 0.10 & 0.14 & 8.47 & 0.80 & 4.18 & 3.75 \\
\hline 9 & 02.10 .2009 & KS.28.01 & 6.91 & 149.50 & 11.40 & 0.35 & 0.03 & 0.01 & 0.35 & 2.32 & 2.20 & 4.74 \\
\hline 10 & 23.11 .2010 & KS.28.02 & 6.38 & 137.70 & - & - & - & - & - & 0.80 & 2.65 & 9.41 \\
\hline 11 & 31.12 .2010 & KS.38.01 & 7.75 & 350.00 & 1.00 & 40.00 & - & - & 3.40 & 1.02 & 10.50 & 1.90 \\
\hline 12 & 31.03 .2015 & KS.40.01 & 7.40 & 108.00 & - & - & - & - & 3.56 & 0.45 & 6.25 & 7.99 \\
\hline 13 & 15.09 .2010 & KS.41.09 & 7.80 & 15.64 & - & - & - & - & - & 0.50 & 0.90 & - \\
\hline 14 & 20.05 .2014 & KS.46.01 & 7.90 & 188.40 & 14.10 & - & - & 0.03 & 0.27 & 0.98 & - & 1.53 \\
\hline 15 & 26.05 .2016 & KS.54.28 & 7.40 & 371.00 & - & - & - & 0.05 & 10.20 & 0.70 & 6.90 & 22.60 \\
\hline 16 & 07.06 .2017 & KS.55.01 & 8.15 & 126.90 & 6.72 & 3.00 & 3.00 & 0.10 & 0.70 & 0.40 & 9.97 & 8.34 \\
\hline 17 & 27.11 .2007 & KS.58.03 & 7.78 & 58.00 & 19.94 & 11.86 & 1.67 & - & - & 1.20 & 2.34 & 2.51 \\
\hline 18 & 11.11 .2011 & İS.60.01 & 7.98 & 271.00 & 66.60 & 55.10 & 2.84 & - & 16.50 & 0.70 & 67.30 & 14.40 \\
\hline \multicolumn{3}{|c|}{ Mean } & 7.58 & 153.24 & 11.82 & 12.89 & 1.23 & 0.06 & 3.48 & 0.86 & 7.79 & 6.23 \\
\hline \multicolumn{3}{|c|}{ Standard Deviation } & 0.44 & 96.63 & 19.24 & 20.31 & 1.20 & 0.05 & 4.87 & 0.52 & 15.64 & 5.51 \\
\hline
\end{tabular}

EC: Electrical Conductivity, $\mathrm{Al}$ : Aluminum, $\mathrm{Fe}$ : Iron, $\mathrm{Mn}$ : Manganese, $\mathrm{NH}_{4}$ : Ammonium, $\mathrm{Cl}$ : Chloride, $\mathrm{O}_{2}$ : Oxidisability, Na: Sodium, $\mathrm{SO}_{4}$ : Sulfate, SD: Standard Deviation in the table.

In this study, only one of the 18 bottled natural water samples collected is manufactured in Sivas province. This water brand manufactured in Sivas is ranked 17th in Table 1. The name of this water 
brand that manufactures in Sivas province is Muratsu Natural Spring Water. This water brand is 105 $\mathrm{km}$ to central of Sivas. Muratsu Natural Spring Water originates from Kösedağ Mountain, which is located at an altitude of 1887 meters in the district of Suşehri in Sivas. There are no any pollutants or industrial areas around the spring water source. Muratsu was established in 2005 and still continues its production with fully automatic machines in Sivas.

\section{DISCUSSION}

Concentrations A total of 18 domestic brands of bottled consisting of natural spring water in Sivas were evaluated by means of physicochemical parameters reported on their manufacturer's labeling. The $\mathrm{pH}$ ranges from 6.38 to 8.20 in the study. Only two bottled water samples were determined just very slightly acidic for it is below 7 unit ( 6.38 and 6.91 respectively). The mean of $\mathrm{pH}$ was found to be $7.58 \pm 0.44$ unit. It can be said that bottled water samples are generally very slightly alkaline. ECDWD (1998), TWRHC (2005) and EPA (2014) recommends standards 6.50-9.50 for $\mathrm{pH}$. The $\mathrm{pH}$ values of all samples seem to meet these acceptable limits for drinking water in Sivas. Although $\mathrm{pH}$ usually has no direct impact on consumers, it is one of the most important operational water quality parameters. No health based guideline value is proposed for $\mathrm{pH}$ (WHO, 2017). The results of this study for $\mathrm{pH}$ were in agreement with the study by Mahajan et al. (2006) from Armitsar, India; Süphandağ et al. (2007) from İstanbul, Turkey; Rabee et al. (2012) from Baghdat, Iraq; Halage et al. (2015) from Kampala, Uganda and Tuluk and Orhan (2017) from Erzurum, Turkey.

The electrical conductivity of the 18 samples was in the range from $15.64 \mu \mathrm{S} / \mathrm{cm}$ to $371.00 \mu \mathrm{S} / \mathrm{cm}$ whereas the ECDWD (1998) and EPA (2014) determined a limit of $2500 \mu \mathrm{S} / \mathrm{cm}$ for drinking water. Therefore, all the bottled water samples were safe for drinking from the electrical conductivity point of view in the present study. Electrical conductivity levels in bottled drinking water obtained in the present study were lower than those obtained by Rabee et al. (2012) from Baghdat, Iraq and Brima (2017) from Najran City, Saudi Arabia. Electrical conductivity levels were similar to these reported in bottled drinking water from İstanbul, Turkey (Süphandağ et al. 2007).

From the result in Table 1, eleven of the eighteen samples contain aluminum and these values range from the lowest $0.21 \mu \mathrm{g} / \mathrm{L}$ to the highest $66.60 \mu \mathrm{g} / \mathrm{L}$. The other 7 samples did not contain aluminum. The aluminum values are limited under the $200 \mu \mathrm{g} / \mathrm{L}$ proposed by ECDWD (1998), TWRHC (2005), EPA (2014) for the quality of drinking water. Current proof does not promote the deriving of a health based guideline value for aluminum in drinking water (WHO, 2017). Similarly, nine of the eighteen samples contain iron and these values range from the lowest $0.35 \mu \mathrm{g} / \mathrm{L}$ to the highest $55.10 \mu \mathrm{g} / \mathrm{L}$. The other 9 samples did not contain iron. These results fall within the maximum permissible level of 200 $\mu \mathrm{g} / \mathrm{L}$ suggested by ECDWD (1998), TWRHC (2005) and EPA (2014) for the quality of drinking water. Iron varies between 500 and $50000 \mu \mathrm{g} / \mathrm{L}$ in natural fresh water. Generally, there is no sensible taste in iron levels below $0.3 \mathrm{mg} / \mathrm{L}$. A health based guideline value for iron is not recommended (WHO, 2017). The mean aluminum, iron and manganese in the present study are found to be $11.82 \pm 19.24 \mu \mathrm{g} / \mathrm{L}, 12.8 \pm 20.31 \mu \mathrm{g} / \mathrm{L}$ and $1.23 \pm 1.20 \mu \mathrm{g} / \mathrm{L}$ respectively. The mean aluminum, iron and manganese levels in bottled water samples obtained in the present study were higher than those obtained by Brima (2017) from Najran City, Saudi Arabia; Singla et al. (2014) from Delhi, India; Tuluk and Orhan (2017) from Erzurum, Turkey.

Only 8 bottled natural water samples contain manganese and the other 10 samples contain no manganese. These 8 values are 1.00, 1.16, 0.07, 0.10, 0.03, 3.00, 1.67 and $2.84 \mu \mathrm{g} / \mathrm{L}$ from the result in Table1. Manganese is naturally occurring in many surface water and groundwater sources, particularly in anaerobic or low oxidation conditions, and this is the most important source for drinking water. At levels exceeding $0.1 \mathrm{mg} / \mathrm{L}$, manganese in water supplies may cause an undesirable taste in beverages and stains sanitary ware and laundry. The presence of manganese in drinking-water, like that of iron, may lead to the accumulation of deposits in the distribution system. Concentrations below $0.1 \mathrm{mg} / \mathrm{L}$ are usually acceptable to consumers. Even at a concentration of $0.2 \mathrm{mg} / \mathrm{L}$, manganese will often form a coating on pipes, which may slough off as a black precipitate. The health based value of $0.4 \mathrm{mg} / \mathrm{L}$ for manganese is higher than this acceptability threshold of $0.1 \mathrm{mg} / \mathrm{l}$. However, under some conditions, manganese can be at concentrations above $0.1 \mathrm{mg} / \mathrm{L}$ and may remain in solution for a longer period compared with its usual solubility in most drinking water (WHO, 2017). These manganese values do not exceed $50 \mu \mathrm{g} / \mathrm{L}$ accepted by ECDWD (1998), TWRHC (2005) and EPA (2014) for drinking water in the present study. 
Nine of the eighteen samples contain ammonium and these values range from the lowest $0.01 \mathrm{mg} / \mathrm{L}$ to the highest $0.15 \mathrm{mg} / \mathrm{L}$. The other 9 bottled water samples did not contain ammonium. There are not important differences for ammonium values among the natural spring waters brands in Sivas. The threshold odour concentration of ammonia at alkaline $\mathrm{pH}$ is approximately $1.5 \mathrm{mg} / \mathrm{L}$, and a taste threshold of $35 \mathrm{mg} / \mathrm{L}$ has been proposed for the ammonium cation (WHO, 2017). Ammonium limit for drinking water is $0.30 \mathrm{mg} / \mathrm{L}$ in EPA (2014). The ammonium values are limited under the 0.50 $\mathrm{mg} / \mathrm{L}$ recommended by ECDWD (1998) and TWRHC (2005). In the present study, ammonium of all samples found to be within the permissible limits.

Fourteen of the eighteen bottled natural water samples contain chloride and these values range from the lowest $0.27 \mathrm{mg} / \mathrm{L}$ to the highest $16.50 \mathrm{mg} / \mathrm{L}$. The other 4 samples did not contain chloride. The chloride values are limited under the $250 \mathrm{mg} / \mathrm{L}$ suggested by ECDWD (1998), TWRHC (2005), EPA (2014) and WHO (2017) for drinking water. Chloride in drinking water originates from natural sources, sewage and industrial effluents, urban runoff containing deicing salt and saline intrusion. High concentrations of chloride give a salty taste to water and beverages. Taste thresholds for the chloride anion depend on the associated cation and are in the range of 200-300 $\mathrm{mg} / \mathrm{L}$ for sodium, potassium and calcium chloride. Concentrations in excess of $250 \mathrm{mg} / \mathrm{L}$ are increasingly likely to be detected by taste, but some consumers may become accustomed to low levels of chloride induced taste. No health based guideline value is proposed for chloride in drinking water (WHO, 2017). The mean value of chloride was found to be $3.48 \pm 4.87$ in Sivas (Table 1). The mean chloride level in bottled drinking water obtained in the present study were lower than those obtained by Pip (2000) from Manitoba, Canada and Brima (2017) from Najran City, Saudi Arabia.

The oxidisability levels of the bottled natural water ranged from 0.20 to 2.32 with a mean of $0.86 \pm 0.52$. In the present study, oxidisability of all bottled water samples found to be below the permissible limit of $5.00 \mathrm{mg} / \mathrm{L}$ recommended by ECDWD (1998), TWRHC (2005) and EPA (2014) for drinking water. Similar findings for oxidisability were found by Tuluk and Orhan (2017) from Erzurum, Turkey.

Seventeen of the eighteen samples contain sulfate and these values range from the lowest $0.80 \mathrm{mg} / \mathrm{L}$ to the highest $22.60 \mathrm{mg} / \mathrm{L}$. The other 1 samples did not contain sulfate. The sulfate results were within the normal acceptable value $250 \mathrm{mg} / \mathrm{L}$ recommended by ECDWD (1998), TWRHC (2005) and EPA (2014). The presence of sulfate in drinking water can cause noticeable taste, and very high levels might cause a laxative effect in unaccustomed consumers. Taste impairment varies with the nature of the associated cation; taste thresholds have been found to range from $250 \mathrm{mg} / \mathrm{L}$ for sodium sulfate to $1000 \mathrm{mg} / \mathrm{L}$ for calcium sulfate. It is generally considered that taste impairment is minimal at levels below $250 \mathrm{mg} / \mathrm{L}$. No health based guideline value has been derived for sulfate (WHO, 2017). The mean value of sulfate was found to be $6.23 \pm 5.51$ in Sivas (Table 1). The mean sulfate level in bottled drinking water obtained in the present study were lower than those obtained by Pip (2000) from Manitoba, Canada and Brima (2017) from Najran City, Saudi Arabia. Sulfate levels were similar to these reported in bottled drinking water from Erzurum, Turkey (Tuluk and Orhan, 2017).

Seventeen of the eighteen samples contain sodium and these values range from the lowest $0.66 \mathrm{mg} / \mathrm{L}$ to the highest $67.30 \mathrm{mg} / \mathrm{L}$. The other 1 samples did not contain sodium. The sodium values are limited under the $200 \mathrm{mg} / \mathrm{L}$ accepted by ECDWD (1998), TWRHC (2005) and EPA (2014). Although concentrations of sodium in potable water are typically less than $20 \mathrm{mg} / \mathrm{L}$, they can greatly exceed this in some countries. The levels of sodium salts in air are normally low in relation to those in food or water. No health based guideline value has been derived, as the contribution from drinking water to daily intake is small. However, concentrations in excess of $200 \mathrm{mg} / \mathrm{L}$ may give rise to unacceptable taste (WHO, 2017). The mean value of sodium was found to be $7.79 \pm 15.64$ in Sivas, Turkey (Table 1). The mean sodium level in bottled drinking water obtained in the present study were lower than those obtained by Brima (2017) from Najran City, Saudi Arabia. Smilarly, the mean sodium levels in bottled water samples obtained in the present study were higher than those obtained by Singla et al. (2014) from Delhi, India; Tuluk and Orhan (2017) from Erzurum, Turkey.

Also, a narrow variability of price was determined in the all samples of Sivas that the $0.5 \mathrm{~L}$ price of bottled natural spring water ranged from a minimum of 0.40 Turkish Lira to a maximum of 1.10 Turkish Lira, while the average with standart deviation was $0.66 \pm 0.18$ Turkish Lira. Even though it brings a financial burden, bottled waters are one of the appropriate ways to meet the water needs of consumers in Sivas. 
National and international water quality standards are set for safe drinking water. Although these standards vary between countries, these differences are very low and the values are very close to each other. It is easier to comply with these standards in bottled waters. In terms of consumers, there is a chance to choose between the water that meets these standards. There are some points that need to be considered when buying bottled healthy drinking water. For this purpose the label, color and physical state of the bottle should be considered. Firstly, the label information of bottled natural spring water should be checked. It is very important to update the values in the labels. Bottled water with a faded label should not be taken. The date of production and expiry should be strictly observed. The color of the bottled water should be clear and clear. It should not be blurry or greenish. Since the sun's rays cause the water to deteriorate quickly, the bottled water that has waited in the sun should not be taken. If the shape of the bottle is defective, it should not be purchased. Nowadays, there are large number of studies on the benefits of high $\mathrm{pH}$ alkaline waters, but the recommended $\mathrm{pH}$ value should be between 6.5-9.5.

\section{CONCLUSION}

Water is the most essential need for life. Limited water resources; with the increasing population, the continuous increase in the need for healthy and safe drinking water requires more efficient use and operation of existing water resources. The present study provides a baseline and benchmark data about the prevailing status of physicochemical quality of the bottled natural spring waters consumed in central of Sivas for future studies. From the present study, it is concluded that all physicochemical quality parameters of bottled natural spring water consumed in Sivas are within acceptable limits according to national and international standards, and do not pose any risk for public health in consumption as drinking water. Therefore, the bottled natural spring water is considered safe for consumption in Sivas.

\section{REFERENCES}

[1] Brima, E.I. (2017). Physicochemical properties and the concentration of anions, major and trace elements in groundwater, treated drinking water and bottled drinking water in Najran area, KSA. Applied Water Science, 7: 401-410.

[2] ECDWD, (1998). Drinking water directive 98/83/EC. Official Journal of the European Communities No: L330, 05 December 1998, 32-54.

[3] EPA, (2014). Drinking water parameters - microbiological, chemical and indicator parameters in the 2014, Drinking Water Regulations 2014. Environmental Protection Agency, Johnstown Castle Estate, Wexford, Ireland, pp 9.

[4] Halage, A.A., Ssemugabo, C., Ssemwanga, D.K., Musoke, D., Mugambe, R.K., Guwatudde, D., Ssempebwa, J.C. (2015). Bacteriological and physical quality of locally packaged drinking water in Kampala, Uganda. Journal of Environmental and Public Health, 2015: 1-6.

[5] KUDAKA, (2012). Bottled drinking water sector. Northeast Anatolia Development Agency, Erzurum, Turkey, pp 18.

[6] Mahajan, R.K., Walia, T.P.S., Sumanjit, B.S.L. (2006). Analysis of physical and chemical parameters of bottled drinking water. International Journal of Environmental Health Research, 16(2): 89-98.

[7] Pip, E. (2000). Survey of bottled drinking water available in Manitoba, Canada. Environmental Health Perspectives, 108(9): 863-866.

[8] Qian, N. (2018). Bottled water or tap water? A comparative study of drinking water choices on university Campuses. Water, 10(59): 1-12.

[9] Rabee, A.M., Emran, F.K., Hassoon, H.A., Al-Dhamin, A.S. (2012). Evaluation of the physco-chemical properties and microbiological content of some brands of bottled water in Baghdad, Iraq. Advances in Bioresearch, 3 (4): 109-115.

[10] Singla, A., Kundu, H., Basavaraj, P., Singh, S., Singh, K., Jain, S. (2014). Physico-chemical and bacterial evaluation of packaged drinking water marketed in Delhi - potential public health implications. Journal of Clinical and Diagnostic Research, 8(3): 246-250.

[11] SUDER, (2018). General structure and numerical size. Bottled Water Producers Association of Turkey, Web Page: http://suder.org.tr/sektor-hakkinda, Date of access: 07.12.2018, İstanbul, Turkey.

[12] Süphandağ, Ş.A., Uyguner, C.S., Bekbölet, M. (2007). The spectroscopic and chemical profiles of commercial and network based drinking waters that are consumed in Istanbul. ITU Journal Serie E: Water Pollution Control, 17(2): 23-35.

[13] Tuluk, B., Orhan, F. (2017). Comparison of tap water with bottled natural spring water in terms of some quality parameters in Erzurum. Research Journal of Agricultural Sciences, 10(2): 27-32. 
[14] TURKSTAT, (2019). The results of address based population registration system. Population of province/district centers and towns/villages and annual growth rate of population by provinces, 2017-2018. Turkish Statistical Institute, Web Page: http://tuik.gov.tr/PreHaberBultenleri.do?id=30709, Date of access: 04.02.2019, Ankara, Turkey.

[15] TWRHC, (2005). Turkish waters regulation for human consumption. Official Journal of Turkey Republic, No: 25730, 17 February 2005, pp 32.

[16] WHO, (2107). Guidelines for drinking water quality: fourth edition incorporating the first addendum. World Health Organization, Geneva, Switzerland, pp 541.

Citation: Seher Dirican, “A Study on Physicochemical Quality of Bottled Natural Spring Waters Consumed in Sivas, Turkey" International Journal of Research Studies In Biosciences (Ijrsb), Vol. 7, no. 6, pp. 11-16, 2019. http://Dx.Doi.org/10.20431/2349-0365.0706003

Copyright: (C) 2019 Authors. This is an open-access article distributed under the terms of the Creative Commons Attribution License, which permits unrestricted use, distribution, and reproduction in any medium, provided the original author and source are credited. 